\title{
Reunion with Self in Terry McMillan's I Almost Forgot About You
}

\author{
Pradip Nathuram Pawar \\ Rajarambapu Institute of Technology, Shivaji University, Kolhapur, \\ Sakharale, Sangli, 415414 (MS), Republic of India \\ $\square$ pradip.pawar@ritindia.edu
}

\begin{abstract}
The novel I Almost Forgot About You by Terry McMillan, which deals with the problem of finding your own identity by studying the components of personality and the context in the formation of identity, is examined. African American feminist literature consists of common themes like sense of being different, managing multiple selves and quest for identity. Terry McMillan's works represent African American female characters' struggle for self-realization that help them in better understanding of the present and planning for the future by reestablishing their identity. The predicament of Georgia, protagonist of the novel, is that she has lost selfhood after subsequent divorces. In due course of time, her role in the family becomes diminished; also she loses interest in the professional life. Her aimlessness and strong desire to restore self leads her to search for male companion among her old boyfriends. She believes that self-satisfaction is possible with exploration of self for that she decides to go on a train trip and tries to focus on nurturing the hobby of woodwork. It helps her in regaining her internal and external self. Thus, the leitmotif of the novel is the search for your own identity as an attempt of inquiry for the destined future.
\end{abstract}

Keywords: identity, self, African American, reunion

Conflicts of interest. The author declares that there is no conflict of interest.

Article history: submitted December 12, 2020; revised December 29, 2020; accepted January 9, 2021.

For citation: Pawar, P.N. (2021). Reunion with self in Terry McMillan's I Almost Forgot About You. RUDN Journal of Studies in Literature and Journalism, 26(1), 85-91. http://dx.doi.org/10.22363/2312-9220-2021-26-1-85-91

\section{Воссоединение с собой в романе Терри Макмиллан «Я почти забыла о тебе»}

\author{
П.Н. Павар
}

Технологический институт Раджарамбапу - филиал Университета Шиваджи, Колхапур Республика Индия, 415414 (MS), Сангли, Сахарале

$\checkmark$ pradip.pawar@ritindia.edu

Аннотация. Исследуется роман Терри Макмиллан «Я почти забыла о тебе», посвященный проблеме поиска себе как личности посредством изучения составляющих личности и контекста в формировании личности. Афроамериканская феминистская ли- 
тература состоит из общих тем, таких как чувство отличия от других, управление множеством себя и поиск себя как личности. Работы Терри Макмиллан воплощают тему борьбы женских персонажей афроамериканцев за самореализацию, что помогает им лучше понимать настоящее и планировать будущее, определять себя как личность. Проблема Джорджии, главной героини романа, состоит в том, что она потеряла себя после разводов. Ее роль в семье уменьшается, она утрачивает интерес к профессиональной жизни. Бесцельное существование и сильное желание найти себя заставляют ее искать партнера среди бывших любовников. Полагая, что самоудовлетворение возможно с помощью изучения себя, она решает отправиться в путешествие на поезде и пытается сосредоточиться на своем хобби - работе по дереву. Это помогает ей восстановить свое внутреннее и внешнее «я». Таким образом, лейтмотивом романа является поиск себя как попытка исследования предначертанного будущего.

Ключевые слова: идентичность, личность, афроамериканец, воссоединение

Заявление о конфликте интересов. Автор заявляет об отсутствии конфликта интересов.

История статьи: поступила в редакцию 12 декабря 2020 г.; принята к публикации 9 января 2021 г.

Для цитирования: Pawar P.N. Reunion with self in Terry McMillan's I Almost Forgot About You // Вестник Российского университета дружбы народов. Серия: Литературоведение. Журналистика. 2021. Т. 26. № 1. С. 85-91. http://dx.doi.org/10.22363/ 2312-9220-2021-26-1-85-91

Dr. Georgia Young, who is an optometrist by profession, is the protagonist of the novel. Her education and degree in optometry was not her wilful decision but to make her father happy. She has an interest in interior designing and carries influences of film and television actors. She is divorced after her second marriage and has two daughters. She is filled with longing for a male companion in her life. Her attempts of self-realization can be noticed in her comment: "I'm trying to stop lying to myself about little things. I'm still working on the big ones" [1. P. 2].

While walking back to home Georgia comes across a woman on the sidewalk, whom Georgia offers some amount. African Americans are affectionate and caring towards poor and service providers. In her semi-autobiographical novel How Stella Got Her Groove Back (2004) Stella calls it as "This is like a black thang: You take care of me, I'll take care of you" [2. P. 62]. Terry's females are sensitive about discriminating treatment of blacks in American society. While watching a movie, Georgia gets disappointed by not finding any black character in it. On arrival of pizza she generously offers tip to Free, a pizza delivery boy who works to arrange his college fees. Free's remarks that no one except a few blacks in this locality gives him any tip after delivery of pizza, points to the communal attachment among African Americans in the US.

William E. Cross, Jr. in his article Black Identity: Rediscovering the Distinction between Personal Identity and Reference Group Orientation concludes that African Americans possess a high sense of personal worth. According to him, there are four variables that provide basis to black identity: self-concept, group identity or reference group orientation (RGO), personal identity (PI), and the relationship between PI and RGO [3. P. 156]. Earlene, Georgia's eighty-one years old mother who is lonely in her home, is conscious of her social identity and to maintain it visits church regularly. She decides to go on a cruise to visit Caribbean islands with some senior regular visitors of the church that is going to help her in endorsing social identity. 
The happenings in life of most of the black women like Georgia and Frankie shows that they are unsatisfied with their male companion. They do not receive love and respect from men in their life. It is recurrent in Terry's novels that the black men are more inclined to white women. When Georgia goes through some old Valentine and birthday cards received from Niles, she dislikes the cards having pictures of white women on the cover of it. This selection of cards by black men indicates their attraction for white women. Though there is dislike for white men among most of the African American women, they never spread hatred about them. Stanley is the white boy in Georgia's list of boyfriends. On Wanda's asking Georgia whether she will have a white boyfriend at present in the twentyfirst century, she replies 'I've never really thought about it. My daughter seems to prefer white boys, and I'm not mad at her, but you know I love me some black men and especially black skin" [1.49-50].

Georgia is not happy with her life; she wants to change her current location and decides to leave her profession also. She plans to sell her share in the clinic but is not sure about making earnings later. Georgia expresses boredom of routine life in words as: "Sometimes you know in your heart it's time to make a change, but the longer you just think about it, the longer the change takes. And since my life is the only thing I do have any control over, I want to start changing some of it" [1. P. 17-18]. She finds no objective in her life and likes to bring changes in it that will delight and will give her a feeling of satisfaction. This is not only the mental state of Georgia but of Terry McMillan's other African American female characters like Stella, Gloria and others. Violet visits Georgia's house to tell her that she needs a break from her routine family and professional life.

From Cleo Strawberry, a daughter of Raymond who was a boyfriend to Georgia in her days of graduation, Georgia comes to know that he is no more. It is the moment that brings about her past memories. On her way home, she thinks about Raymond who was her first love but never expressed it to him. She repents for not expressing her love to him that triggers her to think about the whereabouts of those six to seven men whom she loved once and what they are doing now. Georgia does not want to miss any opportunity to revive those memories. This is why, on receiving the invitation of fortieth class reunion party Georgia immediately decides to attend it. In the process of regaining identity, withdrawing to the past is explained by Elie Ayache as "the only way to regain identity would be to retreat to a time when the difference is not yet determined. Undetermination would thus be the way to evade the difference and to regain identity..." [4. P. 39]. The news of Violet's breast cancer shattered Georgia emotionally. Violet wants to re-establish her relationship with Georgia and Wanda. Regarding this she says "I have no intention of losing my friend. But what in the world am I going to do without her"? [1. P. 243]. Georgia gives importance to her friends this is why Violet's re-entry makes her life happy. Georgia believes that "first you have to have the dream before you walk inside it. Let's keep walking" [1. P. 18]. Georgia makes up mind to find those men with whom she was in love. The search has some purposes like to explore what she has given and received from them, to find the reasons why she loved them and they loved her, to know the reasons of break-up between them, to seek apology from them for her mistakes and to forgive them for their wrongdoings with her and to make them know she never forgets them. She decides to search for her loves with Abraham first. 
Georgia meets Abraham in a club for the first time and gets impressed by him. Though it is shocking for her that he could not complete education, works part-time and stays with his sick mother, she accepts him. Abraham now lives with Georgia in her house and starts dominating her life. It is a common scenario among African American couples in Terry's novels. Georgia expresses her frustration in these words: "...to be perfectly honest he had also started getting on my nerves... As much as I was in love with Abraham's body, I knew I wasn't in love with him" [1. P. 27]. He starts becoming a distraction in her studies that drops down her performance in the college. Meanwhile, she becomes pregnant but does not want to remain in connection with any man through his baby. Abraham leaves Georgia for her decision to reject the baby then after they never meet. Georgia is now looking for Abraham, Oliver, David, Eric, Carter and Lance whom "she (I) was in love with, not the ones she (I) just slept with" [1. P. 35]. Georgia shares about this search with her friend Wanda who appreciates the idea and suggests her to search first for her ex-husbands. Wanda explains, "that way you can see when and how and why you made such bad choices in men, which might help explain why you are still lost and confused" [1. P. 36].

Dependency on parents is a major issue among African American youths. Estelle, Georgia's daughter, always leaves her twin daughters at their grandmother's home and goes for the work. Against her plan, Georgia allows her daughter Frankie and her husband Hunter to stay with her for a few weeks. It shocks Georgia's younger daughter Frankie that her mother put the house on sell because then after Frankie cannot stay long in the house.

Georgia tries to avoid Michael, her ex-husband whom she does not want in her life again. It was a very painful and heartbreaking experience for her when they were parted. Michael has love affair with a girl of his daughter's age. He left Georgia because she shifts her focus from him to her children. Georgia's satisfaction in returning to self helps her to recover from the shock. She expresses it in these words: "I stopped apologizing for being myself. Because I like who I was" [1. P. 68]. On Michael's request, Georgia decides to meet him but does not want to impress him. During their meeting he told her "...I began to get bored with her life, and you seemed more interested in being a good mother, and you were so into your practice - " [1. P. 71]. They relished their memories full of good and bad experiences of each other and parted happily. Georgia presents herself as self-motivated and enjoys the time with him.

Georgia consistently gains weight because she used to find excuses instead of doing some exercise daily. She decides to take care of herself and announces to herself: "I finally get why it's so hard for drug addicts to kick their habit even when they want to. So from this day forward, I'm not going to keep using the same lame-ass excuses for not taking care of myself. And that's final" [1. P. 149]. Inspired by the movie "Before Sunrise" to do something for self satisfaction, Georgia decides to take a train ride. Georgia explains Marina in the following words about her decision to bring change in her life:

"When you get older, you have the understanding that it would be stupid to change what's been working for you, but sometimes you come to your senses and realise you're not happy, you're bored and lonely, you haven't been laid in years, and on top of all this you admit that your profession is dull and unfulfilling and you just decide you're going to break up the monotony..." [1. Pp. 233-234]. 
Most of the Terry's African American women do not receive consistent male support in their familial life and experience disappointment in their relations with men. Georgia's younger daughter Frankie finds her life aimless and parts herself from Hunter, a disloyal husband. While expressing to Georgia her baffled state of mind, Frankie says "I'm confused about what the real purpose of my life is..." [1. P. 85]. African American females of the present century do not find self satisfaction in bearing children and dedication to familial responsibilities. On Georgia's asking about Frankie's pregnancy, she replies that we should not overvalue children in our life. For Georgia, "you can be a woman and be happy without a man and without love. Of course your life has more octane when you have someone to share it with" [1. P. 94].

In his text Principles of Psychology (1890) William James explores the concept of identity for which he uses the term 'self'. According to him, the 'self' has two critical aspects. One is the content that is what one knows about one's self and the other is process that means cognition, motivation, etc. Estelle finds her daughters are confused, they do not understand their presence in all white class in the school. On this, Georgia suggests Estelle, "I just don't think it's healthy for the black kids to go to all - or predominantly white schools... All I'm saying is that it's important they don't grow up confused about their identity" [5. P. 119]. Earlene is very optimistic about life who at the age of eighty-two decides to marry Grover who is "a nice addition" [1. P. 239] to her life. It is surprising to Georgia that Grover is Earlene's boyfriend for more than fifty years. This instigates in Georgia a feeling of absence of male companion in her life that she explains to Wanda in the following words: "You have no idea how much energy it takes and what it feels like to be in my shoes, going on blind dates at my age, hoping I'm going to meet someone wonderful, and it never goes anywhere. It's exhausting [1. P. 150]. She does not want to remain a spinster so decides to search for male company for the rest of her life. Georgia further tells Wanda about her intention behind searching a suitable partner: “...I'm trying to own up to some of my shortcomings, which is one of the reasons I wanted to look into the men from my past to see if maybe they saw then what I'm just learning now or if I inherited some of my unnamed issues from them" [1. P. 150].

For Terry's women, going on a date is one of the socialising activities. Georgia meets James Harvey and Richard with hope to receive one of them as a life partner but she could not make up her mind. Richard, who has crossed his middle age, is dependent on his parents. Later, Georgia goes on a date with James on his cabin cruiser where she comes to know that he has received a research grant and is going to visit India soon. Even at this stage of life Georgia could not find a suitable companion.

As Georgia is searching for her old friends on Facebook, she does not find Lance on it. She immediately guesses that he might be in prison. It points to common observation about criminal mindedness of African American men. Georgia finds Eric, one of her old friends, on Facebook who is in San Francisco. During their interaction on phone, she tells him that she is reinventing herself [1. P. 211]. They come very close to each other as both stay in the same building.

Though Georgia and Abraham were close friends and were in love with each other, she does not have confidence in him. In her meeting with Abraham, 
Georgia expressed her confused state of mind about her future. She tells him: "...I'm trying to figure out what to do next, or with the rest of my life..." [1. P. 221]. Georgia explains to him the reason behind searching her old boyfriends that she does not want her emotions and feelings about them should remain under reach to them. She expresses her feelings of repentance while sharing her experiences with Abraham: "Last year I found out that someone I once cared a lot about had passed away, and I never told him how I really rate about him" [1. P. 226]. Georgia's feeling of dissatisfaction and stagnancy in married life were the major reasons behind her two divorces. Wanda is of the opinion that "...the past doesn't play a role in our present" [1. P. 206] hence, she recommends Georgia to finish her search for a companion.

Earlier, Georgia has decided to sell her house but cannot detach herself from the house. Later, she changes her mind not to sell it. She expresses: "I don't know what I was thinking. I didn't even know where else I wanted to go. As I look around, I realise I like living in this house. It's my house. And it wasn't the house I needed to change. It was me" [1. P. 258]. She removes a signboard of "For Sale" on her house. Georgia realises that she has "spent more time and energy on mistakes than she has (I have) with men who lived up to their image and keep their promises" [1. P. 259]. She now thinks that it is a waste of time to get reconnected with the remaining three men in the list of loves from her past. She learns from her love relations that one should enjoy moments in a relationship. Nobody knows how long this relation or feelings may last. Nobody is perfect and one should not toil to survive fading relations. It is better to find a way out from the situation instead of returning to the finished relations. She develops an interest in woodwork and starts working in the garage. She takes to repair the articles and furniture items in the house; this activity serves her artistic mind. She wants to set up a separate studio to nurture her hobby.

Terry's women are found confused while dealing with racial issues. It is observed through Terry's works that at social level sometimes there is noncooperation from whites but at individual level whites show trust in blacks. Though for their failure in life men held white dominant social system responsible, Terry's women prefer to live among white neighbourhoods because in all black they feel insecure.

Georgia's close ones plan a surprise birthday party for her. Wanda invites Stanley to the party by informing him that Georgia would like to meet her old friends. In their college days, he was in love with Georgia. Though Stanley is a white, he is of the opinion that blacks are citizens of the United States and they should get equal rights as others have. Due to communal differences Georgia maintains distance between them that hurts Stanley and he leaves her at that time. Georgia's birthday party brings them again close to each other where Stanley asks her about a train trip but she avoids answering. Stanley tells Georgia that "We all take a path we thought we wanted to take, and then we find out there are other paths we can still explore" [1. P. 296]. He expresses desire to marry her and invites her to visit his home in New York. Georgia sells her share in the clinic to Lily who is her clinic partner. Finally, she gets on the train "Coast Starlight" [1. P. 341] for her dream journey. Soon the journey starts generating feelings of disappointment in her, because she is eagerly waiting to reach Toronto where Stanley is going to receive her. Georgia compares herself with those "a bunch of weirdos and peo- 
ple who don't know where they are going" and says that "everybody's just so damn lonely" [1. P. 350]. Stanley replies that all of us are trying to find a trustworthy and caring companion, to which she replies by tearing up train tickets.

It is observed when Terry's female especially protagonists leave their comfort zone for exploration of self; they come across opportunities and limitations in exploration and assertion of self [6]. Though Terry's women show psychological strength in different crises like financial, familial, and social; they are found suffering from internal isolation. There is absence of someone who understands their emotions and provides mental support to them. The world around is a hostile place for them that leads them to anxiety, helplessness and depression. In such situations they sometimes remain submissive and tolerant but they never give up attempts of sustaining their individuality and don't compromise with their identity. Terry's female characters are struggling for self-definition and found occupied with addressing difficulties in self-fulfillment.

\section{References}

[1] McMillan, T. (2016). I almost forgot about you. Broadway Books (Penguin Random House LLC).

[2] McMillan, T. (2004). How Stella got her groove back. New American Library, Penguin Group.

[3] Cross, W.E. (1985). Black identity: Rediscovering the distinction between personal identity and reference group orientation. In M.B. Spencer, et al. (Eds.), Beginnings: The Social and Affective Development of Black Children (pp. 155-171). Lawrence Erlbaum Associates, Inc.

[4] Ayache, E. (2010). The blank swan: The end of probability. John Wiley \& Sons.

[5] James, W. (1890). Principles of psychology. Henry Holt and Company.

[6] Pawar, P.N. (2019, June). Quest for identity in the novels of Terry McMillan. Ph.D. Dissertation. Shivaji University, Kolhapur.

\section{Bio note:}

Pradip Nathuram Pawar, Assistant Professor of the Department of Science and Humanities of the Rajarambapu Institute of Technology (affiliated to Shivaji University, Kolhapur). E-mail: pradip.pawar@ritindia.edu.

\section{Сведения об авторе:}

Павар Прадип Натхурам, доцент департамента науки и гуманитарных наук Технологического института Раджарамбапу - филиала Университета Шиваджи, Колхапур. E-mail: pradip.pawar@ritindia.edu. 